\title{
PAPERS
}

OF THE

\section{BRITISH SCHOOL AT ROME}




\title{
PAPERS OF THE \\ BRITISH SGHOOL AT ROME
}

\author{
VOLUME XXVIII \\ (NEW SERIES, VOLUME XV)
}

Ig6o

PUBLISHED BY THE

BRITISH SCHOOL AT ROME at I, LOWTHER GARDENS EXHIBITION ROAD, LONDON, S.W.7 
(C) Copyright The British School at Rome, 1, Lowther Gardens, London, S.W.7

Reprinted by

STEPHEN AUSTIN AND SONS, LTD.

HERTFORD, ENGLAND 


\section{CONTENTS}

PAGE

R. M. Harrison, An Etruscan Cippus in the Ashmolean Museum . . 1

C. C. Van Essen, Two Cippi near Rieti . $\quad$. $\quad$. . . . . . . . $\quad$. 6

D. E. Strong and J. B. Ward-Perkins, The Round Temple in the Forum Boarium

Appendix : The Round Temple and the Hieron at Samothrace

Spencer Corbetr, The Church of SS. Quirico e Giulitta in Rome . . 33

Olwen Brogan and Joyce Reynolds, Seven New Inscriptions from Tripolitania

G. D. B. Jones, Veii : the Valchetta Baths . . . . . .

Walter M. Widrig and Richard Goodchild, The West Church at Apollonia in Cyrenaica . $\quad . \quad$. $\quad . \quad$. . . . .

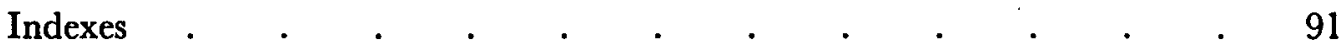

